\title{
Design of An Automatic Follower Shopping Trolley Based on Image Processing
}

\author{
Gheri Febri Ananda ${ }^{1}$, Cici Wahyuni ${ }^{2}$, Ellsa Sania ${ }^{3}$ and Sukardi ${ }^{1}$ \\ ${ }^{1}$ Electrical Engineering Education, Faculty of Engineering, Universitas Negeri Padang \\ ${ }^{2}$ Natural Science Education, Faculty of Mathematics and Natural Science, Universitas Negeri Padang \\ ${ }^{3}$ Physics, Faculty of Mathematics and Natural Science, Universitas Negeri Padang
}

\section{Article Info}

\section{Article history:}

Received July $18^{\text {th }}, 2019$

Revised Aug $18^{\text {th }}, 2019$

Accepted November $18^{\text {th }}, 2019$

\section{Keywords:}

Automatic Trolley

Image

Processing

\begin{abstract}
In the era of industrial revolution 4.0, all human activities are replaced by machines. Humans are required to optimize brain function than muscle function. All human work is facilitated by robots or tools work automatically. For example, shopping activities in the modern market. Consumers prefer to shop in the modern market than the traditional market, because the items are complete, neatly arranged, and they have facilities like trolleys as transporters. Trolleys can be pushed and pulled easily. But when shopping, parents have a problem with pushing or pulling a trolley when they carrying their children. Therefore, we created a design for automatic follower shopping trolley based on image processing which can follow the consumers when shopping. This trolley has a webcam camera as a sensor to take pictures of the objects or special accessories that used by consumers. The result of data are processed in such a way and then it will be obtained the $x$ and y coordinates positions of the consumer and the next data will be sent to the Raspberry Pi 3 which will automatically determine the movement of the trolley. The test results showed that the distance range detected between trolleys and consumers ranged from 0.5 meters to 2 meters, and trolleys can move according to the point where the object was detected. Thus, the trolley can follow the user well.
\end{abstract}

Corresponding Author:

Gheri Febri Ananda,

Jurusan Teknik Elektro, Fakultas Teknik, Universitas Negeri Padang

Jln. Prof. Dr. Hamka Air Tawar, Padang (25131), Sumatera Barat, Indonesia

Email: gherifebriananda@gmail.com

\section{INTRODUCTION}

Shopping is an activity that involves consideration of a product or service, such as finding the best store of providing products or services, looking for desired products and services in the store, and determining the decision to buy such products or services [1]. Shopping activities are more accomplished in the modern market because the items are complete, neatly arranged and they have facilities like trolleys as transporters. Consumers used the trolley by pushing or pulling. But these activities require energy, more effort and less efficient. While shopping in the modern market is more efficient than the traditional market. Therefore, a robot or an automatic trolley is required to be controlled by wireless computer technology [2] so that consumers can move freely without pushing or pulling the trolley. To avoid the occurrence of collisions between the trolley and other objects around the trolley, distance detection is needed by using the ultrasonic sensors [3].

The trolley is designed with the basic principle of image processing using Raspberry Pi3. This method is a technique of image processing or images derived from a webcam sensor to analyze and improve the quality of the image, to be easily interpreted by the machine (computer) or human beings [4] [5]. The previous design used the colour of the shirt as a detected object. Using the colour of clothes as objects do not fit in the public place or modern market [6]. Therefore, in this design, we used special accessories like pins placed at the bottom of the consumer. This webcam will transmit the objects colour data to be processed in Raspberry Pi3 using the Open CV Python software. 


\section{METHOD}

The design of an automatic follower shopping trolley implements an image processing system consisting of three blocks of system diagrams, i.e. input, process, and output. Figure 1 is the diagram block of the system.

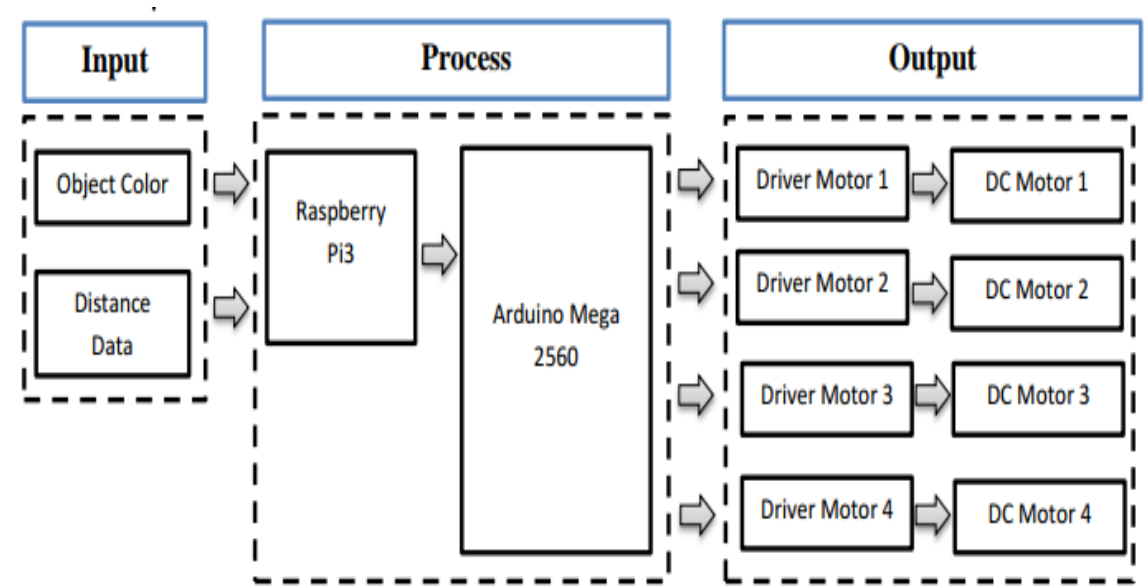

Figure 1 : Block system diagrams

Based of input system blocks, webcam camera is used as a sensor to detect the colour of the object whose data will be processed on Raspberry Pi3 with several stages of image processing using Open CV software with the Python programming language. Here are the image processing stages:

1. Capture Image

At this stage, the webcam will capture the image and the colour data will be sent to Raspberry Pi3 [4].

2. Convert RGB Color to HSV Color

At this stage, the pre-defined object colour with the RGB value (red, green, blue) will be converted to

HSV (hue, saturation, value) using HSV filters on the Open CV Python application [7].

3. Noise removal process (Erosion and Dilation)

Erosion and dilation are used to remove image noises from the HSV's filter results [8].

4. Contours Detection

Contours detection is used in order to get the better detect results that occur a defined contour-shape detection process [9].

5. Hough Circle Transform

This stage is used to detect circles because in this research we use the circle-shaped object to be detected by trolley [10]

6. Character Submission

Once the object has been detected properly, it will be sent as a character describing the coordinates of the position of the detected object to the Arduino microcontroller in the form of $\mathrm{X}$ and $\mathrm{Y}$ coordinates. Figure 2 is the image dividing frames using a resolution of $640 \times 480$ pixels.

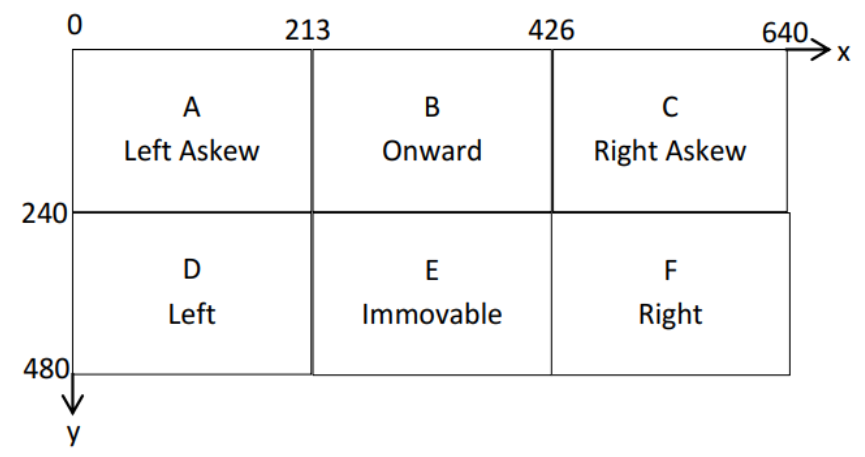

Figure 2 : Frame division 
The character sent to the Arduino, based on the movement of a trolley. The sent character depends on the position of the object, as shown in Figure 3.

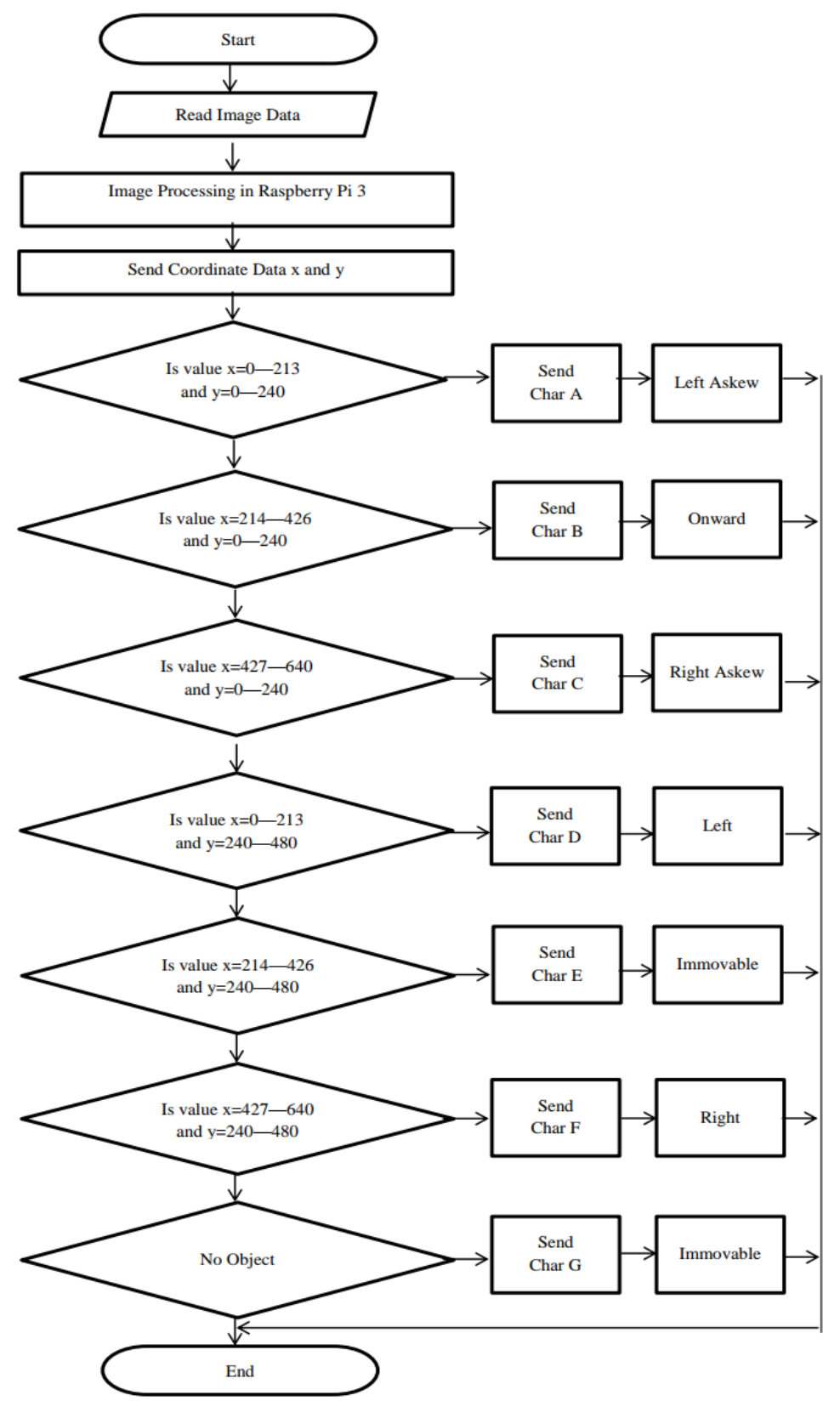

Figure 3. Flowchart of the trolley system

The design of an automatic follower shopping trolley use several components as follows:

1. Arduino Mega 2560

Arduino Mega 2560 is a microcontroller used as a control system on the trolley to receive input signals from Raspberry Pi 3 through serial communication and to control four motor drivers.

2. Logitech Camera C930e

The camera used in this system is a webcam C930e. This C930 webcam serves as an imageshooting or picture-sensing sensor which will then be sent to the Raspberry Pi 3 .

3. Raspberry Pi 3

Raspberry Pi 3 functions as the brain on the trolley that will receive and process the data detected by the webcam and will determine the movement of the trolley.

4. Mechanism Wheel 
The Mechanism wheel is useful as a trolley driver. The wheels can perform left-to-right movements, forward and backward movements, and left and right movements [11].

5. DC Motors $12 \mathrm{~V}$

DC motors are used as the main trolley drivers. The DC motor specification used is the KR13042

which has a torque of $9 \mathrm{Kg} . \mathrm{cm}$ and a rotation speed of $322 \mathrm{rpm}$.

6. Motor Driver

The motor driver is used to control the DC motors speed and direction so that the trolley can move as desired.

7. Ultrasonic Sensors SRF04

Ultrasonic sensors are used to detect the distance between the consumer and the trolley.

8. Lipo Battery $6000 \mathrm{mAh}$

Lipo batteries are used to supply the voltage to the trolley.

9. Power Supply

The power supply is a circuit used to lower the $12 \mathrm{~V}$ battery voltage to $5 \mathrm{~V}$. The form of a circuit can be seen in Figure 4.

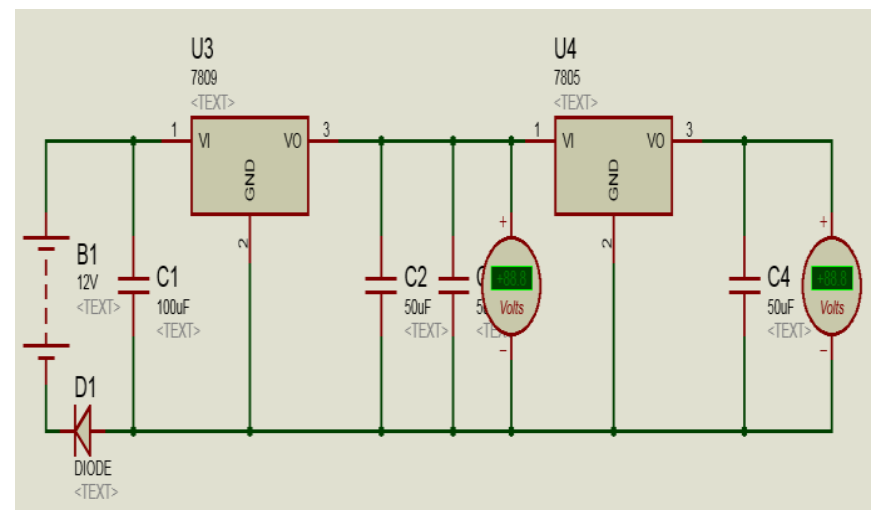

Figure 4 : Power supply circuit

\section{RESULTS AND ANALYSIS}

3.1 Test of Image Processing System on Trolley

Before trolley used directly in the modern market, then need to test image processing system on the trolley. In here done test toward reading distance detection camera as well as delivery each frame data suitable on by Figure 2. The orange accessory is the object used in the design of an automatic follower shopping trolley based on image processing. The resulting test is shown in the following picture and table:

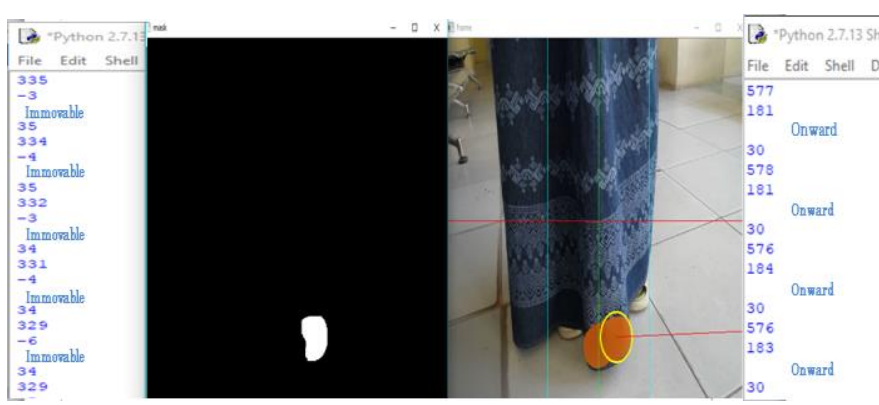

(a)

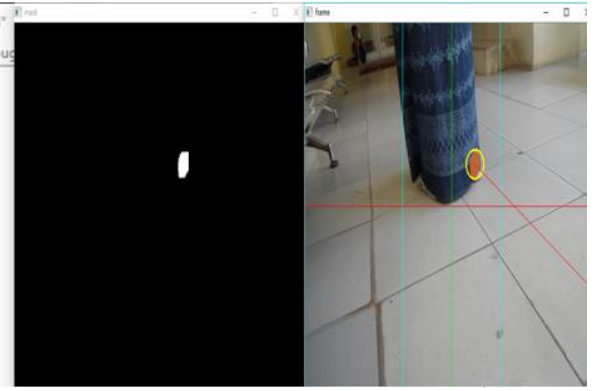

(b)

Figure 5 : Result of reading distance, (a) 0.5 meters; (b) 2 meters

As shown in picture 5(a) the detected object in frame $\mathrm{E}$, the data sent is the instruction to be immovable. Whereas in picture $5(\mathrm{~b})$ the detected object in frame $\mathrm{B}$, the data sent is the instruction to move forward. To reach the algorithm in the distance of 0.5 meters, the object is exactly on frame E. While in frame B is for the distance of 1 up to 2 meters. During 4 times trials, it resulted that the suitable webcam angle for the straight position was $60^{\circ}$. Below is the algorithm testing result : 
Table 1 : Result of reading distance

\begin{tabular}{ccc}
\hline Distance $(\mathrm{m})$ & Information & Decision \\
\hline 0.5 & Detected & Trolley is immovable \\
1 & Detected & Trolley is movable \\
2 & Detected & Trolley is movable \\
3 & Not Detected & Trolley is immovable \\
\hline
\end{tabular}

In Table 1. see that distance can be detected by the camera sensor is 0.5 meters to 2 meters and when the object was on distance 0.5 meters from the trolley, then the trolley is immovable. This algorithm used to keep a safe distance between trolley and user. As shown in Figure 6, the orange circle object was well detected in respective frames. The instruction of trolley movement was successfully sent.

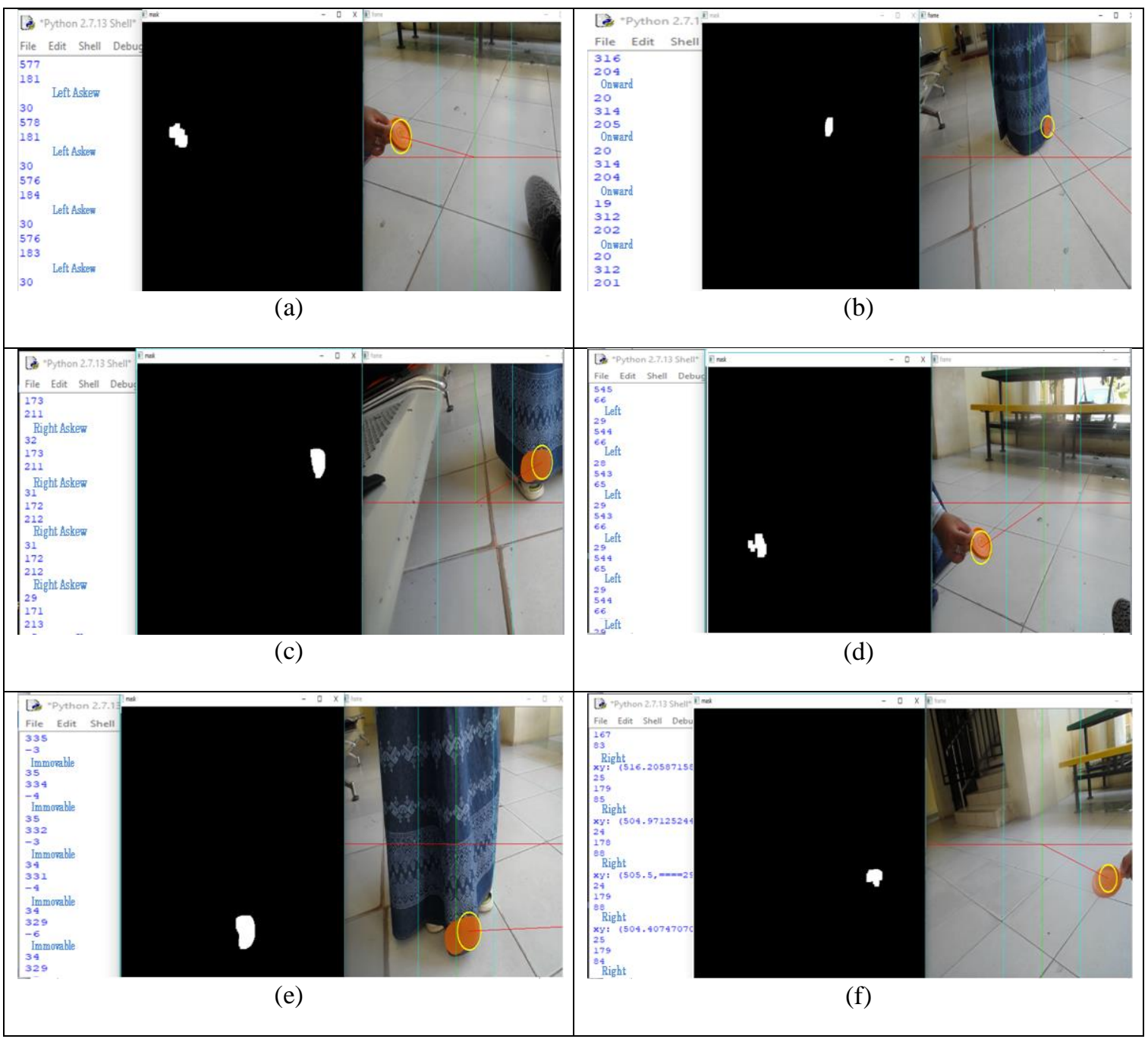

Figure 6 : Result detection in the area of each frame, (a) Frame A; (b) Frame B; (c) Frame C; (d) Frame D; (e) Frame E; and (f) Frame F

Shown in picture 6(a), the object was in frame A, the data sent was left askew. Picture 6(b) in frame $\mathrm{B} \rightarrow$ onward, picture 6(c) in frame $\mathrm{C} \rightarrow$ right askew, picture 6(d) in frame $\mathrm{D} \rightarrow$ left, picture 6(e) frame $\mathrm{E} \rightarrow$ immovable, picture $6(\mathrm{f})$ frame Fright. Below is the testing result when the object in the respective frames. 
Tabel 2 : Results delivery of each data frame

\begin{tabular}{ccc}
\hline Frame Area & Movement & Information \\
\hline A & Left askew & Success \\
B & Onward & Success \\
C & Right askew & Success \\
D & Left & Success \\
E & Immovable & Success \\
F & Right & Success \\
\hline
\end{tabular}

Shown in Table 2, the trolley was movable and followed the customer correctly as the data sent matched the respective frames. This proved that the system of image processing applied to the trolley was able to classify the circle object in the value range RGB determined picture.

\subsection{Testing of Power Supply (Regulator 5V)}

The power supply testing is shown in Figure 7. The measurement result for 12 voltage input resulted 5 Voltage output. The testing conducted 5 times with constant result of 5 Voltage output based on the IC 7805 datasheet. This showed that the power supply was applicable.

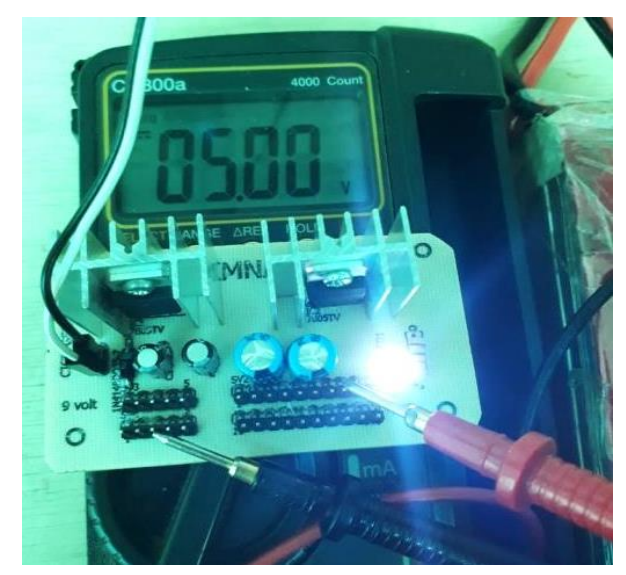

Figure 7 : Power supply 5V test

Table 3 : Result of power supply 5V test

\begin{tabular}{ccc}
\hline Source Tension & Output Tension & Information \\
\hline $12 \mathrm{~V}$ & $5 \mathrm{~V}$ & Success \\
\hline
\end{tabular}

\section{CONCLUSION}

After doing testing and analyzing the design of an automatic follower shopping trolley based on image processing, can be concluded that:

1). The distance can be detected between trolley and user about 0.5 meters to 2 meters. Out of that range, the trolley is immovable.

2). When the distance of trolley and user is 0.5 meter, then the trolley will immovable to keep a safe distance with the user.

3). The trolley can be moved suitable for each frame area. Therefore the trolley can follow user well.

\section{ACKNOWLEDGEMENTS}

In the completion of this scientific article, we realized that the completion process is not detached from the assistance of various parties. For that, we express our gratitude to:

1. The General Directorate of Learning and Student Affairs, Ministry of Research, Technology, and Higher Education, which has given grant funding of 'PKM 2019'.

2. The Chancellor of the Padang State University, which has provided motivation and support to the PKM team that passed funding in 2019. 


\section{REFERENCES}

[1] Huddleston, P., dan Minahan S. 2011. Consumer Behavior: Woman and Shopping. Business Expert Press. New York.

[2] Prasetyawan, P., Ferdianto, Y., Ahdan, S., and Trisnawati, F. 2018. "Pengendali Lengan Robot dengan Mikrokontroler Arduino Berbasis Smartphone". Jurnal Teknik Elektro ITP. 7 (2): 104-109.

[3] Adhitya, A.V., Agustine, L., and Wibowo, A. 2014. "Troli Pengikut Otomatis Berbasis Mikrokontroler AVR". Jurnal Ilmiah Widya Teknik. 13(1).

[4] Fadlullah, M., Darussalam, D.A., Maulana, M., Rovicky, M., Hadi, M.E., Syafarinda, Y., and Yogiswara. 2017. "Implementasi Filter Morfologi Untuk Menghilangkan Noise Objek Pada Robot Sepak Bola". 5th Indonesian Symposium on Robotic Systems and Control 2017 (ISRSC 2017). 6 Juli 2017, Bandung, Indonesia. Page 44-48.

[5] Prasetyo, D., and Abidin, Z. 2017. "Sistem Deteksi Bola Menggunakan Pustaka OPENCV dengan Kombinasi Dua Kamera (Logitech 720p \& Kinnect XBOX 360) di Robot Sepak Bola Beroda". 5th Indonesian Symposium on Robotic Systems and Control 2017 (ISRSC 2017). 6 Juli 2017, Bandung, Indonesia. Page 108-112.

[6] Fanranni, Thamrin, A., Wahab, N.R., and Rudi. 2017. "Sistem Pendeteksian Multi Objek Menggunakan Aplikasi MATLAB Pada Robot 10 - D (Ten - De)". 5th Indonesian Symposium on Robotic Systems and Control 2017 (ISRSC 2017). 6 Juli 2017, Bandung, Indonesia. Page 4-9.

[7] Arinata, G.P., Marzuqi, I., Ramadhan, H., and Khumaidi, A. 2018. "Optimasi Deteksi Bola pada Robot Sepak Bola Beroda Menggunakan Region-based Segmentation". The 6th Indonesian Symposium on Robotic Systems and Control (ISRSC). 10 Juli 2018, Yogyakarta, Indonesia. Page 66-71.

[8] Syaifuddin, M., Prasetyo, D.T., Fahmi, A.B., Afghoni, A.Y., Prasetyo, D., Firdaus N.I., Mahandi, Y.D., and Muladi. 2018. "ROBOSOC UM 2018: Deskripsi Tim Robot KRSBI Beroda Universitas Negeri Malang". The 6th Indonesian Symposium on Robotic Systems and Control (ISRSC). 10 Juli 2018, Yogyakarta, Indonesia. Page 94-98.

[9] Paranto, Y.A., Irfan, S.A., and Nurochman, T. 2018. "Penentuan Posisi Bola berdasarkan Sudut Arah Bola terhadap Robot pada Kamera Omnidirectional". The 6th Indonesian Symposium on Robotic Systems and Control (ISRSC). 10 Juli 2018, Yogyakarta, Indonesia. Page 117-120.

[10] Isnain, M., Ekadinata, A., Lazuardi, H., Sanyoto, Y., Habbie, A. Tjia, Setiawan, J., Ananda, F., Fahrurrozi, A., Putra, R.D., Mi'raj, A., and Husaini, F. 2017. "Sistem Persepsi Berbasis Transformasi Hough pada Robot Sepakbola Humanoid Dago Hoogeschool". 5th Indonesian Symposium on Robotic Systems and Control 2017 (ISRSC 2017). 6 Juli 2017, Bandung, Indonesia. Page 49-54.

[11] Amri, S., Mahadir, Rahmat M., Septiadi, A.R., and Melani, N.S. 2018. "Desain dan Implementasi Komunikasi Control Robot Soccer Beroda Menggunakan User Datagram Protocol (UDP)". 5th Indonesian Symposium on Robotic Systems and Control 2017 (ISRSC 2017). 6 Juli 2017, Bandung, Indonesia. Page 82-88. 